\title{
EXPERIMENTALWORKS
}

UDC 577.151.6:612.04:616.8

doi: https://doi.org/10.15407/ubj91.01.021

\section{ALTERED SIRTUINS 1 AND 2 EXPRESSION \\ IN THE BRAIN OF RATS INDUCED BY EXPERIMENTAL DIABETES AND THE WAYS OF ITS CORRECTION}

\author{
M. M. GUZYK ${ }^{1}$, T. M. TYKHONENKO ${ }^{1}$, K. O. DYAKUN ${ }^{1}$, \\ L. V. YANITSKA', I. B. PRYVROTSKA ${ }^{3}$, T. M. KUCHMEROVSKA ${ }^{1 \bowtie}$ \\ ${ }^{1}$ Palladin Institute of Biochemistry, National Academy of Sciences of Ukraine, Kyiv; \\ ${ }^{2}$ Bogomolets National Medical University, Kyiv, Ukraine; \\ ${ }^{3}$ I. Horbachevsky Ternopil State Medical University, Ukraine;

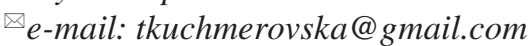

Received: 03 August 2018; Accepted: 13 December 2018

The molecular pathogenesis of diabetic encephalopathy (DE), one of the serious complications of diabetes mellitus, is complex. In this study, we examined whether expression levels of SIRT1 and SIRT2 were the key for the development of brain dysfunctions and whether PARP-1 inhibitors could affect the expression of these proteins for prevention the development of DE in rats with type 1 diabetes. After 10 weeks of the streptozotocin-induced diabetes mellitus (70 mg/kg), Wistar male rats were treated by i.p. injection with PARP-1 inhibitors, 1.5-isoquinolinediol (ISO) or nicotinamide (NAm) (3 or $100 \mathrm{mg} / \mathrm{kg} /$ daily i.p., respectively) for 2 weeks. The rats with blood glucose levels over $19.7 \pm 2.1 \mathrm{mmol} / \mathrm{l}$ were taken into experiments. Western blots were performed to evaluate effects of PAPR-1 inhibitors on the levels of sirtuins, SIRT1 and SIRT2 expression. Diabetes induced significant reduction of SIRT1 expression and SIRT2 overexpression in brain nuclear extracts of diabetic rats compared to non-diabetic control. In brain, NAm attenuated SIRT2 overexpression in nuclear extracts of diabetic rats and slightly elevated SIRT1 expression, while ISO didn't affect expression of both sirtuins in diabetic rats. Furthermore, it was observed that in brain of diabetic rats, the ratio of free NAD/NADH couples decreased 3.1-fold compared to non-diabetic control. The administration of ISO increased only slightly the ratio of free NAD/NADH couples in the brain of diabetic rats while NAm increased this parameter 1.7-fold compared to diabetic rats. Therefore, we concluded that alterations in the expression of SIRT1 and SIRT2 in brain cell nuclei of diabetic rats can lead to the development of brain dysfunctions. One of the neuroprotective mechanisms of NAm action can also be realized through inhibition of SIRT2 expression in brain cell nuclei that down-regulate progression of diabetes-induced alterations and can be a therapeutic option for treatment of brain dysfunctions.

Ke y w o rd s: diabetes mellitus, expression of sirtuins, SIRT1, SIRT2, PARP-1 inhibitors, 1.5-isoquinolinediol (ISO), nicotinamide (NAm).

$\mathrm{T}$ here are increasing evidences that diabetes mellitus (DM) predisposes to cognitive dysfunctions in animal models and humans with both Type 1 (T1DM) and Type 2 (T2DM) diabetes [1-3]. Type 1 diabetic encephalopathy (DE) is likely to increase due to the global increase in the incidence of T1DM and its occurrence especially in younger patients. The molecular pathogenesis of DE, one of the serious complications of diabetes mellitus, is complex and complicated [4, 5]. Many mechanisms are involved in DE development therefore treatment is directed on improvements of cellular

(C) 2019 Guzyk M. M. et al. This is an open-access article distributed under the terms of the Creative Commons Attribution License, which permits unrestricted use, distribution, and reproduction in any medium, provided the original author and source are credited. 
processes which can be potential targets and searching of new therapeutic strategies. Development of diabetic encephalopathy is associated with a complex interplay between neurons, glia and vascular components of the brain. However, the precise molecular mechanisms, underlying development of diabetes-induced brain dysfunctions are not completely elucidated. Numerous evidences including our investigations suggest that activation and/or overexpression of poly(ADP-Ribose)polymerase-1 (PARP-1) in the brain and the retina of diabetic rats in response to excessive DNA damage induce cell death [6, 12]. Moreover, under apoptosis, PARP-1 is cleaved by activated caspase-3 and such limited proteolysis of PARP-1 through this split lead to the enzyme inactivation that further facilitates apoptotic cell death [7]. It is strongly believed that PARP-1 inhibitors to be important factors leading to protection of pathological events in diabetic neuropathy $[8,9]$. Indeed, we have shown that PARP-1 inhibitors reduce inflammation and production of reactive oxygen species (ROS) that activate an apoptotic death program and may contribute to neurodegeneration [10]. Moreover, an additional hallmark of astroglial reactivity is enhanced expression of glial fibrillary acidic protein (GFAP), a major constituent of astrocyte cytoskeleton. GFAP is responsible for morphology support of hypertrophic astrocytes and involved in other glial functional alterations aimed to protect neurons against harmful effects [11].

Thus, possible non-invasive treatment strategy of DE would be aimed to improve expression of NAD-dependent proteins such as special proteins, endogenous deacetylases (SIRT, Silent Information Regulators). Almost in all organisms including bacteria, plants and animals are present NAD-dependent sirtuins [16]. For specialized cells the functioning of the genes that express the proteins necessary for the specific functions of one or another tissue is inherent. Silencing of genes provide sirtuins which belong to the class III histone deacetylases. Noteworthy that mammalian sirtuins are highly regulated at the posttranscriptional level, but at the same time they are also transcriptionally regulated [15]. It is believed that SIRT1 could be a vital mediator providing reduction of calorie intake without malnutrition that is very important for diabetic patients [17-22]. In the nucleus SIRT1 modulates chromatin structure by deacetylating specific lysine residues in histones H1, $\mathrm{H} 3$ and $\mathrm{H} 4$ [23]. Interestingly enough, that in mammals all seven sirtuins, which are homologs to yeast
Sir2, have not only a highly conserved NAD-binding site, but also common catalytic core domain and may act as a mono-ADP-ribosyl transferases and/ or NAD-dependent deacetylases. Despite of SIRT2 was originally described as a cytosolic sirtuin recent findings reveal that it also localized in the nucleus where it regulates cell cycle [28, 29]. SIRT1 functions more investigated in liver, heart, white adipose tissue and skeletal muscle, where it inhibits glycolysis [30].

PARP-1 inhibitors are thought to be ones of the promising approaches to improve brain dysfunctions, because their target is PARP-1 and possibly can be sirtuins. That is why it was important to assess possible positive effects of PARP-1 inhibitors on level sirtuins expression in diabetes mellitus that has not been yet completely investigated. Previously, we have revealed that the amide form of vitamin $B_{3}$ (nicotinamide, NAm) and its derivative, $\mathrm{N}$-methylnicotinamide exert pronounced neuroprotective action and ameliorates diabetes-induced diabetic encephalopathy [12, 13]. Our observations, as well as those of other authors, indicate that 1, 5-isoquinolinediol (ISO), potent inhibitor of inducible nitric oxide synthase (iNOS; NOS II) in mouse macrophages and PARP, has the ability to prevent intensification of angiogenesis in some types of retinopathies [40, 44].

Sirtuins have been involved in key cellular processes, such as cell survival and cell cycle regulation, apoptosis, gene expression control, DNA repair, genome stability stress response, and autophagy [14]. Nevertheless at present very little it is known about role of all sirtuins in the nervous system.

The purpose of present study was to examine the effects of PARP-1 inhibitors, 1.5-isoquinolinediol (ISO) and nicotinamide (NAm), on the expression of SIRT1 and SIRT2 proteins in brain of diabetic rats.

\section{Materials and Methods}

Chemicals and experimental design. All chemicals used were of analytical reagent grade quality and purchased from Sigma Chemical Co. (USA), except for those specified in the text. All procedures fulfilled in accordance with international guidelines and laws for the use and care of laboratory animals and are ethically acceptable. The experiments were performed on male Wistar rats (250-340 g of b.w.), which were maintained in a temperature- and lightcontrolled facility. Rats were fed a standard diet for 12 weeks and had free access to food and water. After 1 week of acclimation, diabetes was induced 
by a single intraperitoneal (i.p.) injection of freshly prepared solution of streptozotocin (STZ) in citrate buffer, $\mathrm{pH} 4.5$ at a dose $70 \mathrm{mg} / \mathrm{kg}$ b.w. Rats of the control group of the same weight, gender and age were intraperitoneally injected only with $0.5 \mathrm{ml}$ of citrate buffer. The animals were maintained on 12-h light/dark cycle and randomly divided into the following groups ( $n=5$ in each group): control rats (Control); diabetic rats (Diabetes, D); diabetic rats after 10 weeks of diabetes were treated by i.p. injection with 1,5-isoquinolinediol (D + ISO) or with nicotinamide (D + NAm) at doses 3 and $100 \mathrm{mg} / \mathrm{kg}$ b. w., respectively, daily for 2 weeks. The dose levels of these compounds and treatment period were chosen on the basis of absence their toxic effects. The rats with blood glucose levels over $19.7 \pm 2.1 \mathrm{mmol} / \mathrm{l}$ were taken into experiments. During the study period body weight and blood glucose were recorded weekly and then in the end of experiments. After 12 weeks experimental rats after a fasting (12 hours) were sacrificed via cervical dislocation under mild diethyl ether narcosis and blood was collected from the retrobulbar venous sinus of the eye. Blood glucose levels were determined using Precision Xtra Plus (MediSense UK Ltd., Great Britain).

Fractioning and separation of brain nuclear proteins. Whole brain tissue immediately was frozen in liquid nitrogen and crushed. Then to $100 \mathrm{mg}$ of the crushed brain tissue was added $0.5 \%$ solution of NP40-PBS containing a mixture of protease inhibitors and phosphatase (Thermo Scientific, USA) for lysis of the cell membranes. The homogenate was stored at $4{ }^{\circ} \mathrm{C}$ for $20 \mathrm{~min}$ [37]. The nuclear extracts of brain tissue were obtained as we described already [10]. A $5 \times$ Laemmli sample buffer was added to the interphase (nuclear fraction of proteins) and boiled for $5 \mathrm{~min}$. The samples were stored at $-80^{\circ} \mathrm{C}$ before analysis.

Electrophoresis of proteins in polyacrylamide gel (PAAG). Electrophoresis of proteins was performed during 3-4 $\mathrm{h}$ in PAAG (8-10\%) in the presence of $0.1 \%$ SDS, using a chamber for electrophoresis, Mini-PROTEAN II (BIO-RAD, Sweden) [38] for subsequent immunoblotting analysis. The molecular mass of proteins in electrophoregrams was determined using standards of proteins obtained from Thermo Scientific (USA) and Fermentas (Lithuania).

Immunoblotting of proteins. Blotting of proteins from PAAG on a nitrocellulose membrane (GE Healthcare, Great Britain) was performed on a Mini Trans-Blot Cell device (BIO-RAD, Sweden) at a voltage of $100 \mathrm{~V}$ during $90 \mathrm{~min}$. At the end of the process, the membrane was stained during 5-10 min with $1 \%$ solution of the Ponceau S dye, prepared on a $3 \%$ solution of trichloroacetic acid. Then, free binding sites on the membrane were blocked during $60 \mathrm{~min}$ by a $5 \%$ solution of skimmed milk powder (APEX Research, USA) in PBS buffer with the addition of $0.1 \%$ Tween-20 (PBSt). Subsequently, the membrane was incubated with primary antibodies in the buffer for blocking overnight at $4{ }^{\circ} \mathrm{C}$; this was followed by washing off with PBSt (three times for $5 \mathrm{~min}$ ). As secondary antibodies, anti-mouse or anti-rabbit IgGs, conjugated with horseradish peroxidase, in dilutions 1:10 000 and 1:1000 in the blocking buffer, respectively, were used. Incubation with secondary antibodies was carried out for $60 \mathrm{~min}$ at room temperature, and then the membrane was washed off with PBSt three times for $5 \mathrm{~min}$. The following antibodies were used in the study: anti-Poly (ADP-ribose) (Trevigen, USA), anti- $\beta$-Actin-Peroxidase (Sigma, USA), anti-SIRT1 (Cell Signaling Technology, USA), anti-SIRT2 (Cell Signaling Technology, USA), anti-mouse IgG (Sigma, USA) and anti-rabbit IgG (Sigma, USA). Immunoreactive zones were detected by measuring the intensity of chemiluminescence [16]. The densitometric analysis was performed using TotalLab TL120 (Nonlinear Inc., USA) software. The protein contents are shown below in arbitrary units (a.u.).

The values of free NAD/NADH couples ratios were calculated from the concentrations of the metabolites (lactate, pyruvate), taking into account the equilibrium constants of the corresponding dehydrogenase systems [39].

Measurement of the proteins content in the samples. Proteins content in the samples was estimated by the Bradford technique [41].

Statistical analysis. Protein contents evaluated by Western blots are expressed in arbitrary units (a.u.) and presented in histograms as mean \pm standard error of the mean (SEM). Quantitative results were analyzed by one-way analysis of variance (ANOVA) followed by Bonferroni post-hoc tests. $P$ values $<0.05$ were considered to indicate statistical significance. Each determination was performed at least in triplicate.

\section{Results and Discussion}

Development of diabetes was accompanied by increase of blood glucose level and body weight loss. It was shown that after 12 weeks of diabetes the average body weight was 1.34 times lower (263 \pm 21 
vs. $353 \pm 32 \mathrm{~g}, P<0.05)$ than that of control group while blood glucose level was elevated $(19.7 \pm 2.1$ vs. $5.2 \pm 0.4 \mathrm{mmol} / \mathrm{l}, P<0.05$ ), this is mean that single STZ injections induced the development of strong uncompensated hyperglycemia. Chronic treatment of diabetic rats with ISO or NAm affected neither body weight nor blood glucose level as compared with untreated diabetic animals. Western blot analysis demonstrated significant down-regulation of SIRT1 expression in brain nuclei of diabetic rats compared to non-diabetic group (Fig. 1).

The reduction in the level of SIRT1 expression in brain of diabetic rats may indicate a violation of its regulatory effect on posttranslational modification of histone and non-gistone proteins in response to cellular stress induced by T1DM, as well as on the process of neuronal precursor cells differentiation. According to literature data activation of SIRT1 expression can have benefitial effect on brain neurons because its activation protects neurons against $\beta$-amyloid-induced toxicity via inhibition of NF- $\mathrm{kB}$

A
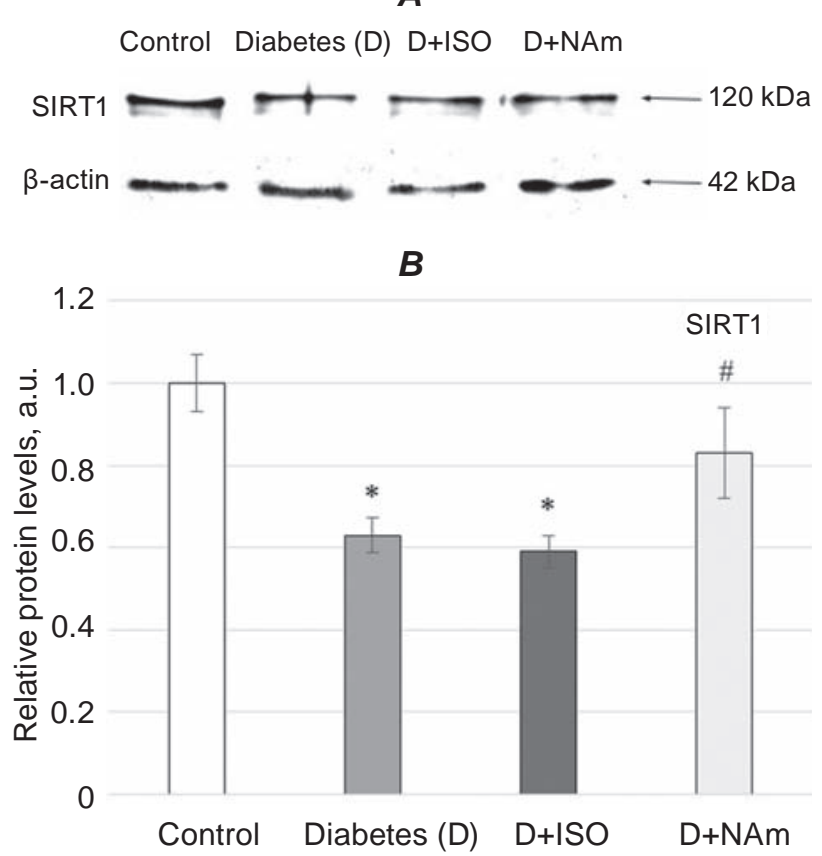

Fig. 1. Effects of ISO or NAm on SIRT1 expression in brain cell nuclei. SIRT1 expression was lower in diabetic rats, while treatment with ISO does not influence its expression, NAm had slight normalizing effect on SIRT1 expression restoration. All values are expressed as mean \pm SEM of three experiments $(n=3)$ in duplicate. $\boldsymbol{A}$ - Blottogram; $\boldsymbol{B}$ - results of densitometry. ${ }^{*} P<0.05$ vs. control; ${ }^{*} P<0.05$ vs. diabetes signalling in microglia [42]. However administration of PARP-1 inhibitors to diabetic rats demonstrated that while ISO had virtually no effect on the expression of SIRT1, NAm slightly increased its expression (Fig. 1). Nevertheless, slight influence of NAm on increasing SIRT1 expression can have protective effect on metabolic processes in brain, altered by T1DM, resulting in a life prolongation [43]. Noteworthy that such slight effect of NAm on SIRT1 expression in the nuclei extracts of brain tissue can be the result of the fact that SIRT1 is not only localized in the nucleus, where it deacetylates histones thereby influencing genes expression [26], but SIRT1 can also shuttle to cytoplasm and through this nucleocytoplasmic mechanism may participate in differentiation and in inhibition of cell death [27]. Moreover, sirtuins are structurally different with regard to their $\mathrm{N}$ - and C-ends, their sub-cellular localization, and their different substrates [24, 25]. It is not excluded that even slight elevation of SIR1expression in turn can lead to activation of 5'-AMP-activated protein kinase which controls energy intake under physiological and pathological conditions [45]. According to literature data SIRT1 activation can be involved in mitochondrial metabolism in conditions of PARP-1 inhibition [36]. So, the data concerning overexpressing SIRT1 in the brain of rats may provide valuable clues as to how SIRT1 realizes its neuroprotective action in vivo. It is known that SIRT1 in the heart increases ischemic tolerance via an activation of eNOS [31] and it also protects against cardiac hypertrophy through PPAR $\alpha$ activation [32]. These data suggest that SIRT1 alterations expression in brain induced by diabetes might impact on encephalopathy development.

At the same time, more than a three-fold increase in the content of NAD-dependent SIRT2 deacetylase in diabetic groups was detected compared to control (Fig. 2), whose elevated content is one of the earliest markers of neurodegenerative processeses development in brain [33]. SIRT2 overexpression can be related to the cell cycle in brain and may be responding on DNA damage induced by diabetes because both deacetylase and mono-ADP-ribosyl tranferase activities have been detected for SIRT2 [24, 35]. It is mean that SIRT 2 acts as a mitotic check point, which, during mitosis, is shuttled from its location in the cytoplasm to the nucleus and may therefore be that SIRT 2 direct inhibits replication [53]. Moreover, the high level of SIRT2 expression in brain can indicate that it may play a role in sensory 
perception [34]. However it is still considerable work to be done to determine the precise role of SIRT2 in the initiation and progression of brain dysfunctions induced by diabetes in vivo. Diabetic rats treated by ISO had no changes in SIRT2 expression in brain cell nuclei as compared to untreated animals (Fig. 2), whereas after NAm administration to diabetic rats its expression was slightly decreased, $P<0.05$.

Therefore, it is not excluded, that exist the connection between the regulatory process under diabetes and level of sirtuins expression in nuclei brain. So, it is mean that sirtuins can become pharmaceutical targets for their modulation and modification. These findings concerning SIRT1 up-regulation and SIRT2 down-regulation are complementary to our previous study showing that PARP-1 inhibition in rats by ISO and NAm increased nicotinamide adenine dinucleotide $\left(\mathrm{NAD}^{+}\right)$content and improved brain functions [10]. However, the molecular role of sirtuins in diabetes still remains completely unclear. To better understand of sirtuin functions we have to determine the complete range of their biochemical and enzymatic activities. It should be noted that despite of the fact that ISO did not influence on SITR1 and SIRT2 expression of nuclei brain the protective mechanism of its action on diabetes-induced brain dysfunction might be realized through its influence on other molecular prosesses in brain. As example ISO can inhibit lipid peroxidation, improve the acetylcholinesterase functioning and partially normalize the levels of GABA and glutamate in the hippocampus [54]. Since PARP-1, SIRT1 and SIRT2 are NADdependent, it is quite obvious that they can compete for the availability of $\mathrm{NAD}^{+}$, reducing not only its content, but also the ratio of free NAD/NADH couples in cells. That is why it was reasonable to evaluate the ratio of free NAD/NADH couples in the brain because it reflects the metabolic state of oxidized and reduced substrates, that is related to two aspects of cellular metabolism: determination the direction of reverse reactions and assessment of alterations of free energy in extracellular oxidoreduction (for example, transport of electrons from NADH to flavoproteins in the electron transport chain [55]. As it is known $\mathrm{NAD}^{+}$plays important role in cellular metabolism and realized its action involving in different a key processes including redox reactions which are regulators of cells functioning [46, 47]. Noteworthy, even insignificant changes in metabolism are accompanied by changes in the free NAD/NADH couples ratio, which in turn causes a change in the flow of carbon to the glycolysis or gluconeogenesis at the
A

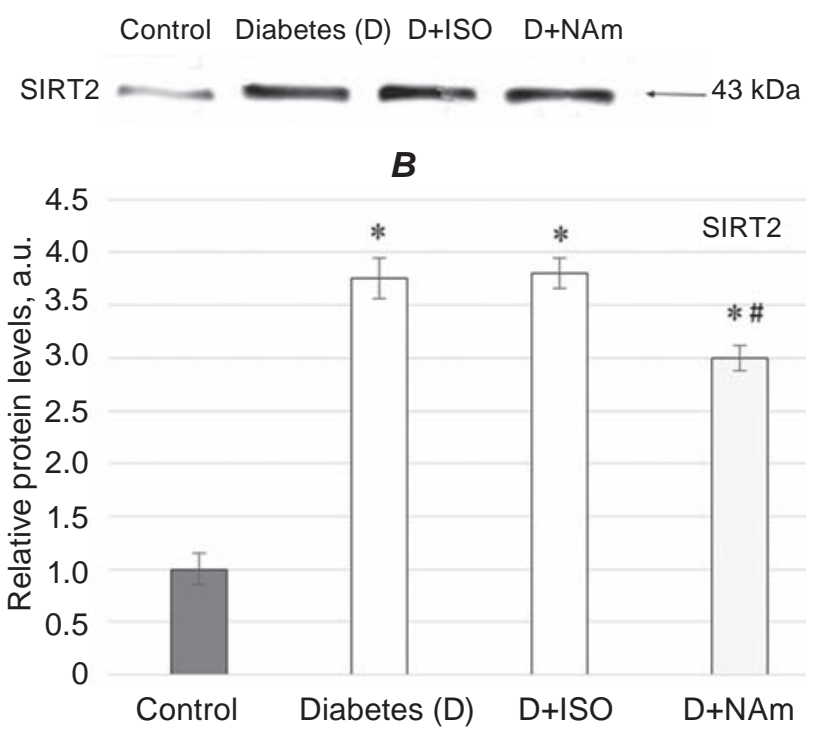

Fig. 2. Western blotting of SIRT2 (43 kDa) in the nuclear extracts of rat brain tissues. A - Representative Western blot and $\mathbf{B}$ - densitometric analysis of SIRT2 protein content. The control values are taken as 1. Statistically significant differences are expressed as mean \pm SEM of three experiments $(n=3)$ in duplicate. ${ }^{*} P<0.05$ vs. control; ${ }^{\#} P<0.05$ vs. diabetes

level of the glyceraldehyde-3-phosphate dehydrogenase reaction [48]. Results obtained in our previously published data revealed that the $\mathrm{NAD}^{+}$content in brain of diabetic rats was reduced [10]. That is why it is not excluded that the ratio of free NAD/ NADH couples also will be changed whereas its maintenance is very important. Indeed, we observed the alterations of metabolites equilibrium concentrations which lead to the reduction of the ratio of free NAD/NADH couples in the brain of diabetic rats to 60.1 versus 186.2 in the control (Fig. 3). Such changes in the oxidation-reduction state can lead to disturbances in the dynamic equilibrium between the oxidation of glucose in NAD-dependent glycolysis and the NADPH-dependent pentose phosphate pathway and enhance DE development.

It was shown that administration of ISO or NAm to diabetic rats lead to slight increase the ratio of free NAD/NADH couples in the brain to 73.4 in case of ISO and more profound for NAm up to 107.5, that may result in the enhanced fuel oxidation and amplification of NAD ${ }^{+}$-dependent SIRT-1 pathway in brain, leading to the improvement of insulin sensitivity and glucose homeostasis. It should 


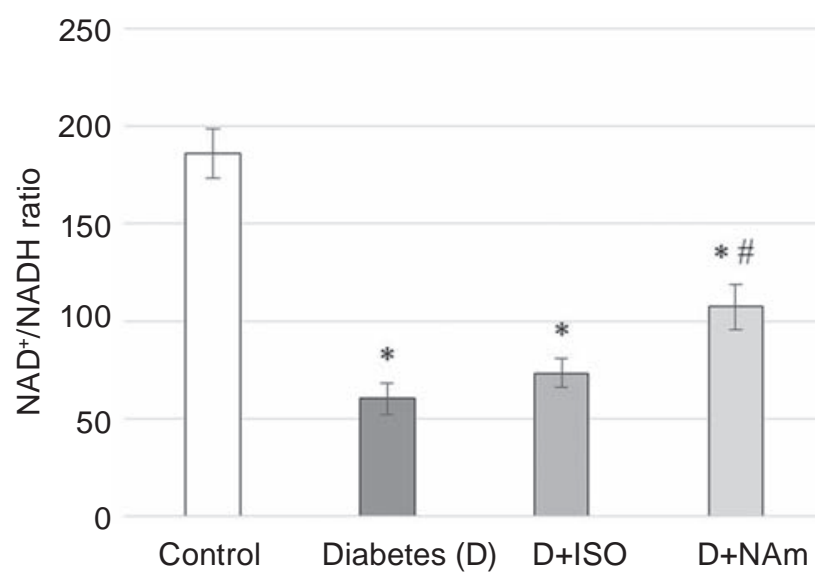

Fig. 3. The ratio of free $N A D / N A D H$ couples in the rat brain, mean $\pm S E M$ of five of experiments. ${ }^{*} P<0.05$ compared to control group, ${ }^{\#} P<0.05$ compared to diabetic group

be noted that our findings are consistent with results concerning Parkinson's disease that does not exclude the common mechanisms of neurodegenerative processes development in the nervous system [52].

In conclusion, it is becoming clear that both SIRT1 and SIRT2 play an important role in brain functioning and alterations of their expression induced by diabetes lead to brain dysfunctions which can be accompanied by cognitive impairment development. However, the results of the present study have shown that among investigated PAPR-1 inhibitors only NAm can partially ameliorate sirtuins expression and improve redox state in brain of diabetic rats. Unlike ISO, anti-diabetic efficacy of NAm may also be associated with formation of 1-methylnicotinamide, one of the endogenous products of NAm, due to its ability to attenuate deleterious effects of diabetes in the CNS as we observed erlier [13]. We also emphasize here that the inhibition of PAPR-1 may be linked with improvement of SIRT1 and SIRT2 functioning during hyperglycemia, possibly due to influence of NAm on the sirtuins expression. More importantly, our results indicate the need to develop more specific modulators of these sirtuins that would not cause any side effects. Therefore these sirtuins can be promising and potential therapeutic targets for treatment of diabetic encephalopathy.

Conflict of interest. Authors have completed the Unified Conflicts of Interest form at http:// ukrbiochemjournal.org/wp-content/uploads/2018/12/ coi_disclosure.pdf and declare no conflict of interest.
ЗМІНА ЕКСПРЕСІЇ СИРТУЇНІВ 1 I 2 В МОЗКУ ЩУРІВ 3 ІНДУКОВАНИМ ЕКСПЕРИМЕНТАЛЬНИМ ДІАБЕТОМ ТА ШЛЯХИ ЇЇ КОРЕКЦІї

\author{
М. М. Гузик', Т. М. Тихоненко ${ }^{1}$, К. О. Дякун ${ }^{1}$, \\ Л. В. Яніиька'ㄹ, I. Б. Привроцьказ, \\ T. М. Кучмеровська
}

${ }^{1}$ Інститут біохімії ім. О. В. Палладіна НАН України, Київ;

${ }^{2}$ Національний медичний університет імені О. О. Богомольця МОЗ України, Київ;

${ }^{3}$ ДВНЗ «Тернопільский державний медичний університет імені І. Я. Горбачевського», Україна;

凶e-mail: tkuchmerovska@gmail.com

Молекулярні механізми патогенезу діабетичної енцефалопатії (ДЕ), одного із серйозних ускладнень цукрового діабету, є складними. $\mathrm{У}$ цій роботі досліджували експресію SIRT1 та SIRT2 як ключову в розвитку дисфункції мозку та можливість інгібіторів PARP-1 впливати на експресію цих протеїнів з метою попередження розвитку ДЕ в щурів із діабетом 1-го типу. Через 10 тижнів розвитку цукрового діабету, індукованого стрептозотоцином (70 мг/кг), щурам-самцям лінії Wistar вводили інгібітори PARP-1, 1,5-ізохіноліндіол (ISO) або нікотинамід (NAm) (3 або 100 мг/кг/добу відповідно) протягом 2 тижнів. В експерименти були взяті щури із рівнем глюкози в крові більше $19,7 \pm 2,1$ ммоль/л. Вестерн-блот аналіз був проведений для оцінки впливу інгібіторів PAPR-1 на рівні експресії SIRT1 та SIRT2. Діабет призводив до значного зниження експресії SIRT1 та надмірної експресії SIRT2 в ядерних екстрактах мозку діабетичних щурів порівняно 3 недіабетичним контролем. Введення NAm пригнічувало надмірну експресію SIRT2 в ядерних екстрактах мозку в діабетичних щурів і незначною мірою підвищував експресію SIRT1, тоді як ISO не впливав на експресію обох сиртуїнів. Більше того, виявлено, що в мозку діабетичних щурів співвідношення вільних NAD/NADH пар було в 3,1 раза нижче порівняно 3 недіабетичним контролем. Застосування ISO спричинювало незначне збільшення співвідношення вільних NAD/NADH пар у мозку діабетичних щурів, тоді як NAm збільшував цей показник у 1,7 раза порівняно 3 діабетичними щурами. Одержані дані свідчать про те, що зміни експресії SIRT1 i SIRT2 в ядрах клітин мозку діабетичних щурів 
можуть призводити до розвитку дисфункцій мозку. Один 3 нейропротекторних механізмів дії NAm також може бути реалізований шляхом гальмування експресії SIRT2 в ядрах клітин головного мозку, що знижує рівень прогресування індукованих діабетом змін і може бути терапевтичним засобом для лікування дисфункцій мозку.

К л ю чов і слов а: цукровий діабет, експресія сиртуїнів, SIRT1, SIRT2, інгібітори PARP-1, 1,5-ізохіноліндіол, нікотинамід.

\section{References}

1. Grünblatt E, Bartl J, Riederer P. The link between iron, metabolic syndrome, and Alzheimer's disease. J Neural Transm (Vienna). 2011; 118(3): 371-379.

2. Monette MC, Baird A, Jackson DL. A metaanalysis of cognitive functioning in nondemented adults with type 2 diabetes mellitus. Can $J$ Diabetes. 2014; 38(6): 401-408.

3. Wong RH, Scholey A, Howe PR. Assessing premorbid cognitive ability in adults with type 2 diabetes mellitus - a review with implications for future intervention studies. Curr Diab Rep. 2014; 14(11): 547.

4. Sima AA. Encephalopathies: the emerging diabetic complications. Acta Diabetol. 2010; 47(4): 279-293.

5. Wayhs CA, Mescka CP, Guerreiro G, Moraes TB, Jacques CE, Rosa AP, Ferri MK, Nin MS, Dutra-Filho CS, Barros HM, Vargas CR. Diabetic encephalopathy-related depression: experimental evidence that insulin and clonazepam restore antioxidant status in rat brain. Cell Biochem Funct. 2014; 32(8): 711-719.

6. Ray Chaudhuri A, Nussenzweig A. The multifaceted roles of PARP1 in DNA repair and chromatin remodelling. Nat Rev Mol Cell Biol. 2017; 18(10): 610-621.

7. Chaitanya GV, Steven AJ, Babu PP. PARP-1 cleavage fragments: signatures of cell-death proteases in neurodegeneration. Cell Commun Signal. 2010; 8: 31.

8. Drel VR, Pacher P, Stavniichuk R, Xu W, Zhang J, Kuchmerovska TM, Slusher B, Obrosova IG. Poly(ADP-ribose)polymerase inhibition counteracts renal hypertrophy and multiple manifestations of peripheral neuropathy in diabetic Akita mice. Int $J$ Mol Med. 2011; 28(4): 629-635.
9. Virág L, Szabó C. The therapeutic potential of poly(ADP-ribose) polymerase inhibitors. Pharmacol Rev. 2002; 54(3): 375-429.

10. Guzyk MM, Dyakun KO, Yanytska LV, Pryvrotska IB, Krynytska IYa, Pishel' IM, Kuchmerovska TM. Inhibitors of poly(ADPribose)polymerase-1 as agents providing correction of brain dysfunctions induced by experimental diabetes. Neurophysiology. 2017; 49(3): 183-193.

11. Sugaya-Fukasawa M, Watanabe T, Tamura M, Egashira S, Hisatomi H. Glial fibrillary acidic protein is one of the key factors underlying neuron-like elongation in PC12 cells. Exp Ther Med. 2011; 2(1): 85-87.

12. Kuchmerovska T, Shymanskyy I, Donchenko G, Kuchmerovskyy M, Pakirbaieva L, Klimenko A. Poly(ADP-ribosyl)ation enhancement in brain cell nuclei is associated with diabetic neuropathy. J Diabetes Complications. 2004; 18(4): 198-204.

13. Kuchmerovska T, Shymanskyy I, Chlopicki S, Klimenko A. 1-methylnicotinamide (MNA) in prevention of diabetes-associated brain disorders. Neurochem Int. 2010; 56(2): 221-228.

14. Verdin E, Hirschey MD, Finley LW, Haigis MC. Sirtuin regulation of mitochondria: energy production, apoptosis, and signaling. Trends Biochem Sci. 2010; 35(12): 669-675.

15. Flick F, Lüscher B. Regulation of sirtuin function by posttranslational modifications. Front Pharmacol. 2012; 3: 29.

16. Haigis MC, Sinclair DA. Mammalian sirtuins: biological insights and disease relevance. Annu Rev Pathol. 2010; 5: 253-295.

17. Chalkiadaki A, Guarente L. Sirtuins mediate mammalian metabolic responses to nutrient availability. Nat Rev Endocrinol. 2012; 8(5): 287-296.

18. Austad SN. Ageing: Mixed results for dieting monkeys. Nature. 2012; 489(7415): 210-211.

19. Bishop NA, Guarente L. Genetic links between diet and lifespan: shared mechanisms from yeast to humans. Nat Rev Genet. 2007; 8(11): 835-844.

20. Jiang H, Medintz I, Zhang B, Michels CA. Metabolic signals trigger glucose-induced inactivation of maltose permease in Saccharomyces. J Bacteriol. 2000; 182(3): 647-654.

21. Mair W, Goymer P, Pletcher SD, Partridge L. Demography of dietary restriction and death in Drosophila. Science. 2003; 301(5640): 17311733. 
22. Cohen MJ, Carstenn S, Lane CR. Floristic quality indices for biotic assessment of depressional marsh condition in Florida. Ecol Appl. 2004; 14(3): 784-794.

23. Utani K, Fu H, Jang SM, Marks AB, Smith OK, Zhang Y, Redon CE, Shimizu N, Aladjem MI. Phosphorylated SIRT1 associates with replication origins to prevent excess replication initiation and preserve genomic stability. Nucleic Acids Res. 2017; 45(13): 7807-7824.

24. Frye RA. Phylogenetic classification of prokaryotic and eukaryotic Sir2-like proteins. Biochem Biophys Res Commun. 2000; 273(2): 793-798.

25. Guarente L. Sirtuins, aging, and metabolism. Cold Spring Harb Symp Quant Biol. 2011; 76: 81-90.

26. Guarente L. Calorie restriction and sirtuins revisited. Genes Dev. 2013; 27(19): 2072-2085.

27. Tanno M, Sakamoto J, Miura T, Shimamoto K, Horio Y. Nucleocytoplasmic shuttling of the $\mathrm{NAD}^{+}$-dependent histone deacetylase SIRT1. J Biol Chem. 2007; 282(9): 6823-6832.

28. Serrano L, Martínez-Redondo P, MarazuelaDuque A, Vazquez BN, Dooley SJ, Voigt P, Beck DB, Kane-Goldsmith N, Tong Q, Rabanal RM, Fondevila D, Muñoz P, Krüger M, Tischfield JA, Vaquero A. The tumor suppressor SirT2 regulates cell cycle progression and genome stability by modulating the mitotic deposition of H4K20 methylation. Genes Dev. 2013; 27(6): 639-653.

29. Imai $S$, Armstrong CM, Kaeberlein $M$, Guarente L. Transcriptional silencing and longevity protein Sir2 is an NAD-dependent histone deacetylase. Nature. 2000; 403(6771): 795-800.

30. Hallows WC, Yu W, Denu JM. Regulation of glycolytic enzyme phosphoglycerate mutase-1 by Sirt1 protein-mediated deacetylation. $J$ Biol Chem. 2012; 287(6): 3850-3858.

31. Mattagajasingh I, Kim CS, Naqvi A, Yamamori T, Hoffman TA, Jung SB, DeRicco J, Kasuno K, Irani K. SIRT1 promotes endothelium-dependent vascular relaxation by activating endothelial nitric oxide synthase. Proc Natl Acad Sci USA. 2007; 104(37): 14855-14860.

32. Planavila A, Iglesias R, Giralt M, Villarroya F. Sirt1 acts in association with PPAR $\alpha$ to protect the heart from hypertrophy, metabolic dysregulation, and inflammation. Cardiovasc Res. 2011; 90(2): 276-284.
33. Yuan F, Xu ZM, Lu LY, Nie H, Ding J, Ying WH, Tian HL. SIRT2 inhibition exacerbates neuroinflammation and blood-brain barrier disruption in experimental traumatic brain injury by enhancing NF- $\kappa \mathrm{B}$ p 65 acetylation and activation. J Neurochem. 2016; 136(3): 581-593.

34. Yu TT, McIntyre JC, Bose SC, Hardin D, Owen MC, McClintock TS. Differentially expressed transcripts from phenotypically identified olfactory sensory neurons. J Comp Neurol. 2005; 483(3): 251-262.

35. Dryden SC, Nahhas FA, Nowak JE, GoustinAS, Tainsky MA. Role for human SIRT2 NADdependent deacetylase activity in control of mitotic exit in the cell cycle. Mol Cell Biol. 2003; 23(9): 3173-3185.

36. Bai P, Cantó C, Oudart H, Brunyánszki A, Cen Y, Thomas C, Yamamoto H, Huber A, Kiss B, Houtkooper RH, Schoonjans K, Schreiber V, Sauve AA, Menissier-de Murcia J, Auwerx J. PARP-1 inhibition increases mitochondrial metabolism through SIRT1 activation. Cell Metab. 2011; 13(4): 461-468.

37. Shaiken TE, Opekun AR. Dissecting the cell to nucleus, perinucleus and cytosol. Sci Rep. 2014; 4: 4923.

38. Laemmli UK. Cleavage of structural proteins during the assembly of the head of bacteriophage T4. Nature. 1970; 227(5259): 680-685.

39. Bergmeyer HU. Methods of Enzymatic Analysis. 1963; 1064 p.

40. Guzyk MM, Tykhomyrov AA, Nedzvetsky VS, Prischepa IV, Grinenko TV, Yanitska LV, Kuchmerovska TM. Poly(ADP-ribose) polymerase-1 (PARP-1) inhibitors reduce reactive gliosis and improve angiostatin levels in retina of diabetic rats. Neurochem Res. 2016; 41(10): 2526-2537.

41. Bradford MM. A rapid and sensitive method for the quantitation of microgram quantities of protein utilizing the principle of protein-dye binding. Anal Biochem. 1976; 72: 248-254.

42. Chen J, Zhou Y, Mueller-Steiner S, Chen LF, Kwon H, Yi S, Mucke L, Gan L. SIRT1 protects against microglia-dependent amyloidbeta toxicity through inhibiting NF-kappaB signaling. J Biol Chem. 2005; 280(48): 4036440374.

43. Satoh A, Brace CS, Ben-Josef G, West T, Wozniak DF, Holtzman DM, Herzog ED, Imai S. SIRT1 promotes the central adaptive 
response to diet restriction through activation of the dorsomedial and lateral nuclei of the hypothalamus. J Neurosci. 2010; 30(30): 1022010232.

44. Rajesh M, Mukhopadhyay P, Godlewski G, Bátkai S, Haskó G, Liaudet L, Pacher P. Poly(ADP-ribose)polymerase inhibition decreases angiogenesis. Biochem Biophys Res Commun. 2006; 350(4): 1056-1062.

45. Jeon SM. Regulation and function of AMPK in physiology and diseases. Exp Mol Med. 2016; 48(7): e245.

46. Katsyuba E, Auwerx J. Modulating NAD(+) metabolism, from bench to bedside. EMBO J. 2017; 36(18): 2670-2683.

47. Cantó C, Menzies KJ, Auwerx J. NAD(+) Metabolism and the control of energy homeostasis: a balancing act between mitochondria and the nucleus. Cell Metab. 2015; 22(1): 31-53.

48. Erecińska M, Wilson DF. Regulation of cellular energy metabolism. J Membr Biol. 1982; 70(1): $1-14$.

49. Momsen G. Effect of increasing the intracellular ratio of $\mathrm{NADH}$ to $\mathrm{NAD}^{+}$on human erythrocyte metabolism: new estimation of the turnover through the phosphoglycerate shunt. Arch Biochem Biophys. 1981; 210(1): 160-166.

50. Milne JC, Lambert PD, Schenk S, Carney DP, Smith JJ, Gagne DJ, Jin L, Boss O, Perni RB, Vu CB, Bemis JE, Xie R, Disch JS, Ng PY, Nunes JJ, Lynch AV, Yang H, Galonek H, Israelian $\mathrm{K}$, Choy $\mathrm{W}$, Iffland $\mathrm{A}$, Lavu $\mathrm{S}$,
Medvedik O, Sinclair DA, Olefsky JM, Jirousek MR, Elliott PJ, Westphal CH. Small molecule activators of SIRT1 as therapeutics for the treatment of type 2 diabetes. Nature. 2007; 450(7170): 712-716.

51. de Kreutzenberg SV, Ceolotto G, Papparella I, Bortoluzzi A, Semplicini A, Dalla Man C, Cobelli C, Fadini GP, Avogaro A. Downregulation of the longevity-associated protein sirtuin 1 in insulin resistance and metabolic syndrome: potential biochemical mechanisms. Diabetes. 2010; 59(4): 1006-1015.

52. Harrison IF, Smith AD, Dexter DT. Pathological histone acetylation in Parkinson's disease: Neuroprotection and inhibition of microglial activation through SIRT 2 inhibition. Neurosci Lett. 2018; 666: 48-57.

53. Inoue T, Hiratsuka M, Osaki M, Oshimura M. The molecular biology of mammalian SIRT proteins: SIRT2 in cell cycle regulation. Cell Cycle. 2007; 6(9): 1011-1018.

54. Jangra A, Datusalia AK, Sharma SS. Reversal of neurobehavioral and neurochemical alterations in STZ-induced diabetic rats by FeTMPyP, a peroxynitrite decomposition catalyst and 1,5-Isoquinolinediol a poly(ADP-ribose) polymerase inhibitor. Neurol Res. 2014; 36(7): 619-626.

55. Hirst J, Roessler MM. Energy conversion, redox catalysis and generation of reactive oxygen species by respiratory complex I. Biochim Biophys Acta. 2016; 1857(7): 872-883. 